\title{
Model Pemberdayaan Konsumen terhadap Ancaman Bahaya Produk Pangan Tercemar Bahan Berbahaya Beracun di Provinsi Lampung
}

\author{
Ahmad Zazili dan Hartono \\ Fakultas Hukum, Fakultas Ilmu Sosial dan Politik Universitas Lampung \\ Jln. Soemantri Brodjonegoro No. 1 Bandar Lampung \\ zazy_01@yahoo.co.id
}

\begin{abstract}
One of the consumer rights is the right for food security. In fact there are still many food products distributed for people not fulfiling the health standard. This research is to study the issues of first: what are the measures taken by government in controlling the food products contaminated by the chemical substances? Second, how is the model of consumer empowerment from the threat of food products contaminated by the chemical additives? The research method used is the empirical-normative law research. Through the library research and elucidation, the result of the research showed first; the controlling measures of government were by prohibiting the use of Formalin, Borax, Rhodamine B, Methyl Yellow as the food additives, and by controlling the distribution of food products. Second, the model of consumer empowerment that can be done is the education for the consumers by spreading the information and elucidation.
\end{abstract}

Key words : Food products, food product, food security, harmful food additives, consumer empowerment

\begin{abstract}
Abstrak
Salah satu hak konsumen adalah hak atas keamanan pangan. Faktanya di masyarakat, masih banyak beredar produk pangan tidak memenuhi standar kesehatan. Penelitian ini mengkaji permasalahan, pertama, apa upaya pemerintah dalam pengendalian produk pangan tercemar bahan kimia. Kedua, bagaimana model pemberdayaan konsumen dari ancaman bahaya produk pangan tercemar bahan tambahan kimia ?. Metode penelitian yang digunakan adalah penelitian hukum normatif-empiris, melalui studi pustaka dan penyuluhan. Hasil penelitian menunjukkan: pertama, upaya pengendalian yang dilakukan pemerintah adalah melarang penggunaan Formalin, Boraks, Rhodamin B, Metil Yellow sebagai bahan tambahan pangan, melakukan pengawasan peredaran produk pangan. Kedua, model pemberdayaan konsumen yang dapat dilakukan adalah pendidikan konsumen dengan cara penyebaran informasi dan penyuluhan.
\end{abstract}

Kata-kata kunci: Produk pangan, keamanan pangan, bahan tambahan pangan berbahaya, pemberdayaan konsumen. 


\section{Pendahuluan}

Masalah keamanan pangan di Indonesia disebabkan cemaran mikroba, cemaran kimiawi, penyalahgunaan bahan berbahaya dan penggunaan bahan tambahan pangan berlebih. ${ }^{1}$ Gambaran keadaan keamanan pangan selama tiga tahun terakhir adalah: (1) Masih ditemukan beredarnya produk pangan yang tidak memenuhi persyaratan; (2) Masih banyak dijumpai kasus keracunan makanan; (3) Masih rendahnya tanggung jawab dan kesadaran produsen serta distributor tentang keamanan pangan yang diproduksi/diperdagangkannya; dan (4) Masih kurangnya kepedulian dan pengetahuan konsumen terhadap keamanan pangan. ${ }^{2}$

Secara nasional pada 2010 Badan Pengawas Obat dan Makanan RI menyatakan, terdapat 592 kasus keracunan yang disebabkan oleh makanan. ${ }^{3}$ Pada 2011 Badan POM telah mencatat 128 kejadian/kasus berasal dari 25 (dua puluh lima) Propinsi, yang terpapar sebanyak 18.144 orang, sedangkan kasus Kejadian Luar Biasa keracunan pangan yang dilaporkan sebanyak 6.901 orang sakit dan 11 orang meninggal dunia. ${ }^{4}$ Kasus terjadinya cemaran produk pangan di Provinsi Lampung berdasarkan hasil temuan Balai Besar Pengawas Obat dan Makanan Bandar Lampung berupa pemusnahan obat tradisional, pangan dan kosmetika hasil pengawasan post-market sepanjang 2009-2012, senilai Rp. 1.023.000.000,00 di empat belas (14) Kabupaten/kota. ${ }^{5}$ Berdasarkan data di atas dapat dikemukakan bahwa banyak produk pangan yang beredar di pasaran tidak aman dikonsumsi sehingga perlu dilakukan pemberdayaan konsumen agar terhindar dari ancaman bahaya pangan tercemar zat kimia.

\section{Rumusan Masalah}

Pokok permasalahan dalam penelitian ini: pertama, bagaimana upaya pemerintah untuk mengendalikan produk pangan tercemar bahan tambahan kimia? kedua,

\footnotetext{
${ }^{1}$ Direktur Inspeksi dan Sertifikasi Pangan, Badan Pengawas Obat dan Makanan (BPOM) Suratmono saat acara media gathering bertema 'Pengawasan Keamanan Pangan', Senin, (16/7/2012); http://health.kompas.com/read/2012/07/17/0718222/Teliti.7.Hal.Ini.Saat.Baca.Label.Makanan, diakses tanggal 1 Maret 2013.

2 Budi Cahyono, Food Safety dan Implementasi Quality System Industri Pangan di Era Pasar Bebas, www.bappenas.go.id, diakses tanggal 11 Maret 2013.

${ }^{3}$ Data statistik 2010, Sentra Informasi Keracunan Nasional Badan Pengawas Obat dan Makanan RI.

${ }^{4}$ Laporan Tahunan 2011 Badan Pengawas Obat dan Makanan.

${ }^{5}$ BBPOM di Bandar Lampung Musnahkan Produk Illegal Senilai 1 Milyar, http://www.pom.go.id,di akses tanggal 3 Maret 2013.
} 
bagaimanakah model pemberdayaan konsumen yang dapat dilakukan dalam menghindari ancaman bahaya produk pangan tercemar bahan tambahan kimia?

\section{Tujuan Penelitian}

Tujuan penelitian ini: pertama, mengetahui dan menganalisis upaya pemerintah dalam pengendalian produk pangan tercemar bahan tambahan kimia. Kedua, menemukan model pemberdayaan konsumen dalam menghindari ancaman bahaya produk pangan tercemar bahan tambahan kimia.

\section{Metode Penelitian}

Penelitian ini bersifat normatif-empiris, yaitu mengkaji peraturan perundangundangan yang berkenaan dengan keamanan pangan dan mengkaji efektifitasnya. Data yang dipergunakan terdiri dari data primer dan data sekunder. Data primer berasal dari wawancara dengan pejabat di Balai Besar Pengawas Obat dan Makan Bandar Lampung, Dinas Kesehatan Kota Metro Propinsi Lampung, serta penyebaran quisioner terhadap masyarakat Lampung yang tersebar di 6 kabupaten/kota. Sedangkan data sekunder terdiri dari bahan hukum primer, berupa peraturan perundang-undangan dan jurnal yang relevan dengan permasalahan. Bahan hukum sekunder terdiri dari buku, majalah, artikel Koran dan laporan penelitian. Bahan hukum dikumpulkan melalui metode kepustakaan berupa pengumpulan peraturan perundang-undangan yang berkaitan dengan keamanan pangan dan dianalisis secara deskriptif kualitatif.

\section{Hasil Penelitian dan Pembahasan}

\section{Pengendalian Produk Pangan Tercemar Bahan Tambahan Kimia}

Pangan adalah kebutuhan dasar manusia paling utama, karena itu pemenuhan pangan merupakan bagian dari hak asasi individu. Pemenuhan pangan juga sangat penting sebagai komponen dasar untuk mewujudkan sumber daya manusia yang berkualitas. Pangan merupakan kebutuhan jasmani yang tak terelakkan, oleh karena begitu pentingnya pangan bagi umat manusia di dunia, maka hak atas pangan dilindungi dan dijamin dalam Deklarasi Hak Asasi Manusia 1948 Artikel 11 (1) yaitu: "Everyone has the right to standard living dequate for the health and well 
being of himself and of his family, including food". ${ }^{6}$ Menurut Undang-Undang No. 18 Tahun 2012 tentang Pangan (UU Pangan), Pangan adalah segala sesuatu yang berasal dari sumber hayati produk pertanian, perkebunan, kehutanan, perikanan, atau minuman. Produk secara umum diartikan sebagai barang yang secara nyata dapat dilihat, dipegang (tangible goods), baik yang bergerak maupun yang tidak bergerak,7 sedangkan dalam peternakan, perairan, dan air, baik yang diolah maupun tidak diolah yang diperuntukkan sebagai makanan atau minuman bagi konsumsi manusia, termasuk bahan tambahan pangan, bahan bakupPangan, dan bahan lainnya yang digunakan dalam proses penyiapan, pengolahan, dan/atau pembuatan makanan pengertian luas produk adalah segala barang dan jasa yang dihasilkan oleh suatu proses sehingga produk berkaitan erat dengan teknologi. ${ }^{8}$

Dalam proses produksi pangan, produsen menggunakan bahan tambahan pangan (BTP). Menurut Food and Agricalture Organization, BTP adalah senyawa yang sengaja ditambahkan ke dalam makanan dengan jumlah dan ukuran tertentu dan terlibat dalam proses pengolahan, pengemasan, dan atau penyimpanan. Bahan ini berfungsi untuk memperbaiki warna, bentuk, cita rasa, dan tekstur, serta memperpanjang masa simpan dan bukan merupakan bahan (ingredient) utama. ${ }^{9}$ Dalam Pasal 73 UU Pangan disebutkan bahwa BTP merupakan bahan yang ditambahkan ke dalam pangan untuk mempengaruhi sifat dan/atau bentuk pangan. Secara umum bahan tambahan pangan adalah bahan yang biasanya tidak digunakan sebagai makanan dan biasanya bukan merupakan komponen khas makanan, mempunyai atau tidak mempunyai nilai gizi, yang dengan sengaja ditambahkan dalam makanan dengan maksud teknologi pada pembuatan, pengolahan penyimpanan, perlakuan, pengepakan, pengemasan, dan penyimpanan. ${ }^{10}$ Penggunaan BTP memiliki tujuan untuk meningkatkan atau

\footnotetext{
${ }^{6}$ Laporan Penelitian Hukum, "Tanggung Jawab Pemerintah Dalam Menjamin Perlindungan Pangan (Perbandingan Dengan Beberapa Negara)", Badan Pembinaan Hukum Nasional RI, Jakarta, 2013, hlm. 54 hlm.64.

${ }^{7}$ Adrian Sutedi, Tanggung Jawab Produk Dalam Hukum Perlindungan Konsumen. Ghalia Indonesia, Bogor, 2008,

${ }^{8}$ Janus Sidabalok, Hukum Perlindungan Konsumen Di Indonesia Dengan Pembahasan Atas Undang-Undang Nomor 8 Tahun 1999, PT Citra Aditya Bakti, Bandung, 2006, hlm.18.

${ }^{9}$ Cahyo Saparinto dan Diana Hidayati, Bahan Tambahan Pangan, Kanisius, Yogyakarta, 2006, hlm. 8

10 Wisnu Cahyadi, Analisise Aspek Kesehatan Bahan Tambahan Pangan, PT Bumi Aksara, Jakarta, 2006, hlm. 
mempertahankan nilai gizi dan kualitas daya simpan, membuat bahan pangan lebih mudah dihidangkan, serta mempermudah preparasi bahan pangan.11

Dilihat dari bentuknya BTP digolongkan menjadi dua kelompok besar, yaitu sebagai berikut: 1. BTP yang sengaja ditambahkan dengan sengaja ke dalam makanan, dengan mengetahui komposisi bahan tersebut dan maksud penambahan itu dapat mempertahankan kesegaran, cita rasa, dan membantu pengolahan, sebagai pengawet, pewarna dan pengeras; 2. BTP yang tidak sengaja ditambahkan, yaitu bahan yang tidak mempunyai fungsi dalam makanan tersebut, terdapat secara tidak sengaja, baik dalam jumlah sedikit atau cukup banyak akibat perlakuan selama proses produksi, pengolahan, dan pengemasan. Bahan ini dapat pula merupakan residua tau kontaminan dari bahan yang sengaja ditambahkan untuk tujuan produksi bahan mentah atau penanganannya yang masih terus terbawa ke dalam makanan yang akan dikonsumsi. Contoh BTP dalam golongan ini adalah residu pestisid. ${ }^{12}$

Secara khusus tujuan penggunaan BTP adalah untuk: 1. Mengawetkan pangan dengan mencegah pertumbuhan mikroba perusak pangan atau mencegah terjadinya reaksi kimia yang dapat menurunkan mutu pangan; 2. Membentuk pangan menjadi lebih baik, renyah dan lebih enak dimulut; 3. Memberikan warna dan aroma yang lebih menarik sehingga menambah selera; 4. Meningkatkan kualitas pangan; 5. Menghemat biaya.

Langkah yang dilakukan pemerintah dalam rangka pengendalian produk pangan tercemar bahan tambahan kimia, yaitu sebagai berikut: mengeluarkan kebijakan pelarangan penggunaan bahan tambahan pangan kimia yang membahayakan kesehatan manusia; melakukan pengawasan terhadap produk pangan yang beredar; melakukan penegakan hukum terhadap pelaku usaha yang melanggar penggunaan larangan bahan tambahan pangan; melakukan sosialisasi kepada masyarakat.

Pelarangan penggunaan BTP kimia berupa formalin, boraks, rhodamin b, metil yellow sebagai BTP diatur dalam Undang-Undang Nomor 8 Tahun 1999 tentang Perlindungan Konsumen, Undang-Undang Republik Indonesia Nomor 36 Tahun

11 Ibid.

12 Ibid, hlm. 1-2 
2009 tentang Kesehatan, Undang-Undang Nomor 18 Tahun 2012 tentang Pangan, Peraturan Pemerintah Nomor 69 Tahun 1999 tentang Label dan Iklan Pangan, Peraturan Menteri Kesehatan Republik Indonesia Nomor 033 Tahun 2012 tentang Bahan Tambahan Pangan, Peraturan Menteri Kesehatan Nomor 239/Menkes/Per/V/1985 tentang Zat Warna Tertentu yang Dinyatakan Sebagai Bahan Berbahaya, Peraturan Bersama Menteri Dalam Negeri Republik Indonesia dan Kepala Badan Pengawas Obat dan Makanan Republik Indonesia Nomor: 43 Tahun 2013/Nomor: 2 Tahun 2013 tentang Pengawasan Bahan Berbahaya Yang Disalahgunakan Dalam Pangan. Pelarangan tersebut dalam rangka jaminan keamanan pangan yang dikonsumsi masyarakat dan dalam upaya pemenuhan hak-hak konsumen terhadap keamanan pangan.

Materi Hukum yang diatur dalam peraturan perundang-undangan yang terkait dengan pelarangan penggunaan BTP berbahaya diuraikan sebagai berikut:

\section{Undang-Undang Nomor 8 Tahun 1999 tentang Perlindungan Konsumen}

Pasal 4 UU No. 8 Tahun 1999 menentukan hak konsumen yaitu: Hak atas kenyamanan, keamanan dan keselamatan dalam mengkonsumsi barang dan/atau jasa; Hak untuk memilih barang dan/atau jasa serta mendapatkan barang dan/atau jasa tersebut sesuai dengan nilai tukar dan kondisi serta jaminan yang dijanjikan; Hak atas informasi yang benar, jelas dan jujur mengenai kondisi dan jaminan barang dan/atau jasa; Hak untuk didengar pendapat dan keluhannya atas barang dan/atau jasa yang digunakan; Hak untuk mendapatkan advokasi, perlindungan dan upaya penyelesaian sengketa perlindungan konsumen secara patut; Hak untuk mendapat pembinaan dan pendidikan konsumen; Hak untuk diperlakukan atau dilayani secara benar dan jujur serta tidak diskriminatif; Hak untuk mendapatkan kompensasi, ganti rugi/penggantian, apabila barang dan/atau jasa yang diterima tidak sesuai dengan perjanjian atau tidak sebagaimana mestinya; Hak-hak yang diatur dalam ketentuan peraturan perundang-undangan lainnya.

Selain mengatur tentang hak konsumen, juga menentukan kewajiban pelaku usaha yang dapat ditemukan pada Pasal 7 huruf D yang menyatakan: Kewajiban pelaku usaha adalah menjamin mutu barang dan/atau jasa yang diproduksi 
dan/atau diperdagangkan berdasarkan ketentuan standar mutu barang dan/atau jasa yang berlaku. Ketentuan ini dipertegas kembali pada Pasal 8 yang menyatakan: (1) Pelaku usaha dilarang memproduksi dan/atau memperdagangkan barang dan/atau jasa yang tidak memenuhi atau tidak sesuai dengan standar yang dipersyaratkan dan ketentuan peraturan perundangundangan. Ketentuan di atas mengandung makna bahwa pelaku usaha dilarang menggunakan formalin, boraks, rhodamin $b$, metal yellow sebagai BTP sebab dapat menimbulkan bahaya kesehatan bagi konsumen. Hal ini sesuai ketentuan bahwa pelaku usaha wajib menjamin mutu barang dan/atau jasa yang diproduksi dan/atau diperdagangkan berdasarkan ketentuan standar mutu barang dan/atau jasa yang berlaku.

\section{Undang-Undang Republik Indonesia Nomor 36 Tahun 2009 tentang Kesehatan}

Ketentuan tentang pentingnya aspek keamanan produk pangan terdapat dalam Pasal 109, Setiap orang dan/atau badan hukum yang memproduksi, mengolah, serta mendistribusikan makanan dan minuman yang diperlakukan sebagai makanan dan minuman hasil teknologi rekayasa genetik yang diedarkan harus menjamin agar aman bagi manusia, hewan yang dimakan manusia, dan lingkungan. Berdasarkan ketentuan di atas dapat dinyatakan bahwa setiap produk yang akan dipasarkan maka harus ada jaminan tidak membahayakan keamanan dan kesehatan dengan demikian, pelaku usaha dilarang menggunakan bahan tambahan pangan yang dapat membahayakan kesehatan manusia. Ketentuan di atas dipertegas dalam Pasal 111 menyatakan: Makanan dan minuman yang dipergunakan untuk masyarakat harus didasarkan pada standar dan/atau persyaratan kesehatan; Makanan dan minuman hanya dapat diedarkan setelah mendapat izin edar sesuai dengan ketentuan peraturan perundang-undangan.

\section{Undang-Undang Nomor 18 Tahun 2012 tentang Pangan}

Ketentuan tentang keamanan pangan diatur dalam Pasal 68, yang menyatakan: Pemerintah dan Pemerintah Daerah menjamin terwujudnya penyelenggaraan Keamanan Pangan disetiap rantai Pangan secara terpadu; Pemerintah menetapkan norma, standar, prosedur, dan kriteria Keamanan Pangan; Petani, Nelayan, 
Pembudi Daya Ikan, dan Pelaku Usaha Pangan wajib menerapkan norma, standar, prosedur, dan kriteria Keamanan Pangan; Penerapan norma, standar, prosedur, dan kriteria Keamanan Pangan dilakukan secara bertahap berdasarkan jenis Pangan dan skala usaha Pangan.

Ketentuan di atas menentukan tentang salah satu kewajiban pemerintah dan pemerintah daerah yaitu menyelenggarakan sistem pangan yang aman. Ketentuan ini merupakan landasan hukum bagi pemerintah dan pemerintah daerah untuk mengeluarkan kebijakan-kebijakan atau langkah-langkah dalam upaya menciptakan sistem keamanan pangan. Kewenangan pemerintah dalam menentukan kebijakan keamanan pangan diatur dalam Pasal 86 yang menyatakan: Setiap Orang yang memproduksi dan memperdagangkan Pangan wajib memenuhi standar Keamanan Pangan dan Mutu Pangan, Pemenuhan standar Keamanan Pangan dan Mutu Pangan sebagaimana dimaksud pada ayat dilakukan melalui penerapan sistem jaminan Keamanan Pangan dan Mutu Pangan". Pemerintah dan/atau lembaga sertifikasi yang terakreditasi oleh Pemerintah dapat memberikan sertifikat Jaminan Keamanan Pangan dan Mutu Pangan.

\section{Peraturan Pemerintah Nomor 28 Tahun 2004 tentang Keamanan, Mutu dan Gizi Pangan}

Dalam peraturan pemerintah ini diatur secara khusus tentang BTP, yaitu pada Pasal 11, bahwa "Setiap orang yang memproduksi pangan untuk diedarkan dilarang menggunakan bahan apapun sebagai BTP yang dinyatakan dilarang". Bahan yang dinyatakan terlarang ditetapkan oleh Kepala Badan. Dalam pasal ini secara tegas dinyatakan bahwa produsen, penjual dilarang untuk menggunakan bahan tambahan pangan yang dilarang. Pelarangan ini dalam rangka untuk melindungi konsumen dari produk pangan yang tidak aman untuk dikonsumsi. Penegasan tentang larangan mengedarkan pangan yang tidak aman diatur pada Pasal 23 "Setiap orang dilarang mengedarkan: pangan yang mengandung bahan beracun, berbahaya atau yang dapat merugikan atau membahayakan kesehatan atau jiwa manusia; pangan yang mengandung cemaran yang melampaui ambang batas maksimal yang ditetapkan; pangan yang mengandung bahan yang dilarang digunakan dalam kegiatan atau proses produksi pangan; pangan yang 
mengandung bahan yang kotor, busuk, tengik, terurai, atau mengandung bahan nabati atau hewani yang berpenyakit atau berasal dari bangkai sehingga menjadikan pangan tidak layak dikonsumsi manusia; atau pangan yang sudah kedaluwarsa".

Peraturan Menteri Kesehatan Republik Indonesia Nomor 033 Tahun 2012 tentang Bahan Tambahan Pangan.

Permenkes ini mengatur tentang jenis-jenis BTP yang dilarang digunakan pada makanan yaitu pada Pasal 8, Bahan yang dilarang digunakan sebagai Bahan Tambahan Pangan sebagai berikut: Asam borat dan senyawanya (Boric acid); Asam salisilat dan garamnya (Salicylic acid and its salt); Dietilpirokarbonat (Diethylpyrocarbonate, DEPC); Dulsin (Dulcin); Formalin (Formaldehyde); Kalium bromat (Potassium bromate); Kalium klorat (Potassium chlorate); Kloramfenikol (Chloramphenicol); Minyak nabati yang dibrominasi (Brominated vegetable oils); Nitrofurazon (Nitrofurazone); Dulkamara (Dulcamara); Kokain (Cocaine); Nitrobenzen (Nitrobenzene); Sinamil antranilat (Cinnamyl anthranilate); Dihidrosafrol (Dihydrosafrole); Biji tonka (Tonka bean); Minyak kalamus (Calamus oil); Minyak tansi (Tansy oil); Minyak sasafras (Sasafras oil).

Peraturan Bersama Menteri Dalam Negeri Republik Indonesia dan Kepala Badan Pengawas Obat dan Makanan Republik Indonesia Nomor: 43 Tahun 2013/Nomor: 2 Tahun 2013 tentang Pengawasan Bahan Berbahaya Yang Disalahgunakan Dalam Pangan.

Peraturan bersama ini bertujuan melindungi masyarakat dari pangan yang mengandung bahan berbahaya dan untuk mencegah penyalahgunaan bahan berbahaya dalam pangan serta perkuatan pengawasan yang dilakukan oleh Badan Pengawas Obat dan Makanan bersama dengan Kementerian Dalam Negeri selaku pembina dan pengawas penyelenggaraan pemerintahan daerah.

Pada Pasal 3 dinyatakan "Pengawasan Bahan Berbahaya yang disalahgunakan dalam pangan dilakukan terhadap jenis bahan berbahaya antara lain: Asam Borat; b. Boraks; c. Formalin (larutan formaldehid); d. Paraformaldehid (Serbuk dan Tablet Paraformaldehid); Pewarna Merah Rhodamin B; Pewarna Merah Amaranth; Pewarna Kuning metanil (Methanil Yellow); dan Pewarna 
Kuning Auramin". Berdasarkan peraturan bersama, perlu dibentuk tim pengawasan terpadu yang terdiri dari: Menteri dan Kepala Badan POM dalam melaksanakan pengawasan membentuk Tim Pengawas Terpadu Pusat; Gubernur dalam melakukan pengawasan di tingkat provinsi membentuk Tim Pengawas Terpadu Provinsi; Bupati/Walikota dalam melakukan pengawasan membentuk Tim Pengawas Terpadu Kabupaten/Kota. Menindaklanjuti peraturan bersama ini, Pemerintah Provinsi Lampung telah menerbitkan Peraturan Gubernur No. 36 Tahun 2013 tentang Sistem Keamanan Pangan Terpadu di Provinsi Lampung. Langkah-langkah yang telah dilakukan adalah melakukan inspeksi mendadak atau pemantauan ke sejumlah pasar tradisional dan pasar swalayan di Bandarlampung, hasil yang ditemukan adalah masih terdapat produk pangan yang menggunakan zat kimia Rhodamin B.

Di Provinsi Lampung instansi pemerintah yang bertugas secara khusus melakukan pengawasan dan pengendalian produk pangan tercemar adalah Balai Besar Pengawas Obat dan Makanan Bandar Lampung (BBPOM). BBPOM Bandar Lampung merupakan Unit Pelaksana Teknis Badan POM di daerah, BBPOM Bandar Lampung melaksanakan tugas dan fungsinya berdasarkan Keputusan Kepala Badan POM Nomor HK.00.05.21.4232 Tahun 2004 tentang Perubahan atas Keputusan Kepala Badan POM RI Nomor Nomor: 05018/SK/KBPOM tahun 2001 tentang Organisasi dan Tata Kerja Unit Pelaksana Teknis di Lingkungan Badan POM, yang mempunyai tugas melaksanakan kebijakan dibidang pengawasan produk terapetik, narkotika, psikotropika dan zat adiktif lain, obat tradisional, kosmetik, produk komplemen, keamanan pangan dan bahan berbahaya. Dalam melaksanakan tugas menyelenggarakan fungsi: ${ }^{3}$ 1. Menyusun rencana dan program pemeriksaan dan penyidikan obat dan makanan; 2. Pelaksanaan pemeriksaan setempat pengambilan contoh untuk pengujian, dan pemeriksaan sarana produksi, distribusi dan pelayanan kesehatan dibidang produk terapetik, narkotika, psikotropika dan zat adiktif lainnya, obat tradisional, kosmetik, produk komplemen, pangan dan bahan berbahaya; 3. Pelaksanaan penyidikan kasus pelanggaran hukum di bidang produk terapetik, narkotika, psikotropika dan zat

${ }^{13}$ Laporan Tahunan Badan Pengawas Obat dan Makanan Lampung Tahun 2013 
adiktif lainnya, obat tradisional, kosmetik, produk komplemen, pangan dan bahan berbahaya; 4 . Evaluasi dan penyusunan laporan pemeriksaan dan penyidikan obat dan makanan.

Berdasarkan wawancara dengan Ibu Evita Ariestiana selaku Pengawas Fungsional Makanan Pelaksana Lanjutan BBPOM ${ }^{14}$ menyatakan bahwa upaya pengendalian yang dilakukan BBPOM Lampung adalah dengan melakukan pengawasan pre-market yaitu pengawasan pada saat proses produksi ke Perusahaan-perusahaan yaitu Perusahaan Industri Rumah Tangga, serta pembinaan berupa sosialisasi tentang bahan tambahan pangan yang dilarang dan yang diperbolehkan, serta sosialisasi mengenai bahan pengganti bahan tambahan pangan kimia. Langkah pengendalian yang lain adalah melakukan pengawasan post market yaitu pengawasan terhadap sarana distribusi, yaitu pengawasan atau pengecekan terhadap produk pangan yang dijual di pasar-pasar seperti mall, toko, minimarket.

Upaya pengendalian yang lain adalah melakukan uji laboratorium terhadap sampel makanan dan minuman. Hasil uji lab dapat diketahui ada yang memenuhi syarat atau tidak memenuhi syarat. Terhadap produk pangan yang tidak memenuhi syarat kesehatan maka dilakukan pemberian surat peringatan untuk tidak menjual produk pangan lagi, menariknya dari peredaran, penghentian sementara produksi pangan, serta dilakukan penutupan tempat usaha dengan cara pencabutan ijin usaha yang dilakukan oleh dinas atau instansi yang berwenang. Selanjutnya diuraikan bahwa upaya lain yang dilakukan oleh BBPOM Bandar Lampung adalah dengan melakukan sosialisasi melalui program sispom, yaitu berupa penyebaran informasi kepada masyarakat mengenai produk pangan yang mengandung bahan berbahaya melalui radio, televisi dan majalah POM Lampung.

Jika dicermati upaya yang dilakukan BBPOM Bandar Lampung dalam pengendalian produk pangan tercemar sudah tepat sudah sesuai dengan tugas pokok dan fungsi POM sebagaimana diamanahkan dalam Pasal 68 UU Pangan, yang menentukan:

14 Wawancara di Bandar Lampung, 5 September 2015. 
(1)Pemerintah dan Pemerintah Daerah menjamin terwujudnya penyelenggaraan Keamanan Pangan disetiap rantai Pangan secara terpadu.

(2)Pemerintah menetapkan norma, standar, prosedur, dan kriteria Keamanan Pangan;

(3)Petani, Nelayan, Pembudi Daya Ikan, dan Pelaku Usaha Pangan wajib menerapkan ; norma, standar, prosedur, dan kriteria Keamanan Pangan sebagaimana dimaksud pada ayat (2);

(4)Penerapan norma, standar, prosedur, dan kriteria Keamanan Pangan sebagaimana dimaksud pada ayat (3) dilakukan secara bertahap berdasarkan jenis Pangan dan skala usaha Pangan.

Akan tetapi upaya tersebut belum mampu menjangkau semua lapisan masyarakat sasarannya masih terbatas hal ini karena adanya keterbatasan sumberdaya yang dimiliki sedangkan wilayah kerja sangat luas yaitu 13 kabupaten/kota se propinsi Lampung, terkait dengan hal tersebut diperlukan keterlibatan pihak lain dalam upaya penyampaian informasi kepada konsumen menyangkut informasi keamanan pangan.

Keterangan lain yang dikemukakan oleh Evita Ariestiana, bahwa untuk mengatasi kekurangan personel dan sumber daya dalam melakukan pengawasan maka dibentuk tim satuan tugas yang beranggota masyarakat yang berperan melakukan pengawasan dan melakukan sosialisasi terhadap produk pangan yang tercemar, salah satu contohnya adalah satgas di pelelangan ikan di Lempasing Bandar Lampung yang secara aktif melakukan pemantauan dan pembinaan kepada pedagang ikan untuk tidak menggunakan formalin sebagai pengawet ikan. Upaya pembentukan tim satuan tugas ini merupakan suatu langkah maju dan baik karena melibatkan masyarakat, akan tetapi pola ini memiliki kelemahan sebab hanya menjangkau lokasi pelelangan ikan saja sedangkan ketika ikan sudah dibeli dan dibawa ke pasar-pasar oleh para pedagang maka satgas tidak melakukan pengawasan lagi.

Upaya yang dapat dilakukan dalam mengatasi keterbatasan BBPOM Bandar Lampung dalam melakukan pembinaan dan pengawasan maka dilakukan kerja sama dengan lembaga pemerintah daerah yaitu dengan satuan kerja daerah seperti Dinas Perikanan, Dinas Kesehatan dan lain-lain. Kerjasama yang dilakukan khususnya mengenai kegiatan sosialisasi mengenai keamanan pangan yaitu dengan cara mengundang tokoh masyarakat, tokoh agama, pemuda yang berjumlah 40 orang yang tersebar di kabupaten/kota di propinsi Lampung. Jika dicermati langkah kerjasama ini juga belum maksimal sebab jumlahnya masih sedikit sehingga belum menjamin informasi yang diperoleh dari hasil sosialisasi akan disampaikan kepada masyarakat yang lain. Hasil 
pengawasan yang dilakukan Balai Besar Pengawas Obat dan Makanan Lampung Tahun 2013 dapat dilihat pada table berikut ini.

Tabel 1.

Jenis Bahan Berbahaya dalam Sampel Pangan 2013

\begin{tabular}{|lllc|}
\hline No & Nama Produk Pangan & Nama Bahan Berbahaya & Jumlah \\
\hline 1 & Apem & Rhodamin B & 5 \\
2 & Bakso Ikan & Formalin & 1 \\
3 & Cenil & Rhodamin B & 2 \\
4 & Es Campur & Rhodamin B & 11 \\
5 & Es Cendol & Rhodamin B & 7 \\
6 & Es Cincau & Rhodamin B & 3 \\
7 & Harum Manis & Rhodamin B & 4 \\
8 & Jelly & Rhodamin B & 1 \\
9 & Jipang & Rhodamin B & 1 \\
10 & Kelanting & Rhodamin B & 16 \\
11 & Kerupuk Singkong & Rhodamin B & 8 \\
12 & Kuping Gajah & Rhodamin B & 2 \\
13 & Opak & Rhodamin B & 4 \\
14 & Pacar Cina & Rhodamin B & 12 \\
15 & Putu Mayang & Rhodamin B & 2 \\
16 & Sagon & Rhodamin B & 1 \\
\hline
\end{tabular}

(Sumber data: Laporan tahunan BBPOM Lampung 2013)

Jika diperhatikan data di atas maka dapat dinyatakan bahwa penyalahgunaan bahan tambahan pangan yang dilarang yaitu Rhodamin B, hal ini sungguh memprihatinkan. Konsumen dalam ancaman bahaya zat kimia yang sangat berpengaruh terhadap kesehatan.

Selanjutnya berdasarkan uji sampling terhadap produk pangan di Lampung pada 2013 yang dilakuan BBPOM Bandar Lampung dengan jumlah sampel pangan yang diuji pada 2013 sebanyak 2.641 terdiri dari sampel rutin 1050, Mobil keliling 1545, uji Profisiensi 3 sampel dan sampel luar 43. Sampel seluruhnya telah selesai diuji dengan hasil 2.328 atau 88,15\% sampel memenuhi syarat dan 313 sampel atau $11,85 \%$ tidak memenuhi syarat. Sampel Tidak Memenuhi Syarat dikarenakan : Kadar Air, Kadar Abu; Pengawet melebihi batas; Bahan Berbahaya : Rodamin B, boraks dan formalin.15

Di Kota Metro Propinsi Lampung pengawasan terhadap produk pangan yang beredar dilakukan oleh Dinas Kesehatan, pelaksanaan pengawasan ini didasarkan 
pada Peraturan Daerah Kota Metro Nomor 12 Tahun 2010 tentang Perubahan atas Peraturan Daerah Kota Metro Nomor 07 Tahun 2008 Tentang Pembentukan, Organisasi dan Tata Kerja Perangkat Daerah Kota Metro, Pasal 12 (1) Dinas Kesehatan mempunyai tugas melaksanakan sebagian urusan pemerintahan daerah berdasarkan asas otonomi dan tugas pembantuan dibidang Kesehatan; (2) Untuk melaksanakan tugas tersebut, Dinas Kesehatan menyelenggarakan fungsi: a. Perumusan kebijakan teknis dibidang Pengendalian Penyakit dan Penyehatan Lingkungan, Pelayanan Kesehatan, Sumber Daya Manusia dan Pemberdayaan Masyarakat serta Kesehatan Keluarga dan Gizi; b. Penyelenggaraan urusan pemerintahan dan pelayanan umum dibidang Pengendalian Penyakit dan Penyehatan Lingkungan, Pelayanan Kesehatan, Sumber Daya Manusia dan Pemberdayaan Masyarakat serta Kesehatan Keluarga dan Gizi;

Berdasarkan keterangan Eko Supriyono16, Fungsionaris Seksi Farmasi, Makanan, Minuman dan Alat Kesehatan Dinas Kesehatan Metro bahwa pengawasan dilakukan ke pusat-pusat perbelanjaan, pasar tradisional, kantin sekolah, pelaku Pangan Industri Rumah Tangga. Selain itu dilakukan uji sampel terhadap produk pangan yang beredar di masyarakat. Sedangkan upaya lain yang dilakukan dalam pengendalian terhadap produk pangan yang beredar di pasaran dengan cara melakukan penyebaran informasi kepada masyarakat melalui tokoh masyarakat, kader Pembinaan Keluarga Kesejahteraan, tokoh pemuda. Dalam melakukan pengawasan terhadap produk pangan yang beredar belum dapat menjangkau semua produk pangan dan wilayah hukum kota Metro, hal ini karena adanya keterbatasan peralatan dan sumber pendanaan.

\section{Model Pemberdayaan Konsumen terhadap Ancaman Bahaya Produk Pangan Tercemar Bahan Tambahan Kimia}

Istilah konsumen berasal dari kata consumer (Inggris-Amerika) atau consument (Belanda). Secara harfiah arti kata consumer adalah lawan dari produsen, setiap orang yang menggunakan barang. ${ }^{17}$ Di beberapa negara konsumen memiliki pengertian yang saling berbeda satu sama lain. Di Amerika Serikat pengertian "konsumen" yang berasal dari kata consumer berarti "pemakai", namun dapat juga

16 Wawancara di Kota Metro Provinsi Lampung, 3 Oktober 2014.

17 A.Z. Nasution, Hukum Perlindungan Konsumen, Diadit Media, Jakarta, 2002, hlm. 3. 
diartikan lebih luas lagi sebagai "korban pemakaian produk yang cacat", baik korban tersebut pembeli, bukan pembeli tetapi pemakai, bahkan korban yang bukan pemakai, karena perlindungan hukum dapat dinikmati pula oleh ko rban yang bukan pemakai.18 Pengaturan perlindungan konsumen di Amerika Serikat diatur dalam The Uniform Trade Practices and Consumer Protection Act tahun 1967, yang kemudian diamandemen dengan Unfair Trade Practices dan Consumer Protection (Lousiana) Law 1973. Sedangkan di Perancis berdasarkan doktrin dan yurisprudensi yang berkembang mengartikan konsumen sebagai "the person who obtains goods or services for personal or family purposes". Dari definisi di atas terkandung dua unsur, yaitu (konsumen hanya orang dan barang atau jasa yang digunakan untuk keperluan pribadi atau keluarganya. ${ }^{19}$ Di India sebagaimana terdapat dalam Protections Act No. 68 of 1986 Article 2 (i) "consumer" means any person who- (i) buys any goods for a consideration which has been paid or promised or partly paid and partly promised, or under any system of deferred payment and includes any user of such goods other than the person who buys such goods for consideration paid or promised or partly paid or partly promised, or under any system of deferred payment when such use is made with the approval of such person, but does not include a person who obtains such goods for resale or for any commercial purpose. Konsumen adalah setiap orang (pembeli) atas barang yang disepakati, menyangkut harga dan cara pembayarannya, tetapi tidak termasuk mereka yang mendapatkan barang untuk dijual kembali atau lain-lain keperluan komersial). ${ }^{20}$ Perlindungan Konsumen di Malaysia diatur dalam Malaysia's Consumer Protection Act 1999, defines "consumer" as a person who "acquires or uses goods or services of a kind ordinarily acquired for personal, domestic or household purposes, use or consumption; and does not acquire or use the goods or services, or hold himself out as acquiring or using the goods or services, primarily for the purpose of resupplying them in trade; consuming them in the course of a manufacturing process; or in the case of goods, repairing or treating, in trade, other goods or fixtures on land". ${ }^{21}$ Sedangkan di Indonesia pengertian konsumen sesuai Pasal 1

${ }^{18}$ Celina Tri Siwi Kristiyanti, Hukum Perlindungan Konsumen, Sinar Grafika, Jakarta, 2009, hlm. 23.

${ }^{19} \mathrm{Ibid}$.

${ }^{20}$ Ibid, hlm. 4.

21 Mohamad Fazli Sabri, "The Development of Consumer Protection Policies in Malaysia" International Journal of Business and Social Research 4.6 (2014): 98-108, hlm. 100. 
angka 2 Undang-Undang No. 8 Tahun 1999 tentang Perlindungan Konsumen, Konsumen adalah setiap orang pemakai barang dan/atau jasa yang tersedia dalam masyarakat, baik bagi kepentingan diri sendiri, keluarga, orang lain, maupun makhluk hidup lain dan tidak untuk diperdagangkan. Menurut A.Z. Nasution, orang yang dimaksud di atas adalah orang alami bukan badan hukum. Sebab yang memakai, menggunakan dan atau memanfaatkan barang dan atau jasa untuk kepentingan diri sendiri, keluarga, orang lain maupun makhluk hidup lain dan tidak untuk diperdagangkan hanyalah orang alami atau manusia.22 Secara lebih spesifik batasan-batasan mengenai konsumen, yaitu sebagai berikut: konsumen akhir adalah setiap orang yang mendapatkan barang atau jasa digunakan untuk tujuan tertentu; konsumen antara, adalah setiap orang mendapatkan barang dan/atau jasa untuk digunakan dengan tujuan membuat barang atau jasa lain untuk diperdagangkan; konsumen akhir, adalah setiap orang yang mendapatkan dan menggunakan barang dan/atau jasa untuk tujuan memenuhi kebutuhan hidupnya pribadi, keluarga dan atau rumah tangga dan tidak untuk diperdagangkan kembali.23

Ada empat hak dasar konsumen yaitu hak untuk mendapatkan keamanan (the right to safety), hak untuk mendapatkan informasi (the right to be informed), hak untuk memilih (the right to choose), dan akhirnya hak untuk didengar (the right to be heard ). ${ }^{24}$ Ada empat alasan pokok perlunyan perlindungan konsumen ${ }^{25}$ yaitu sebagai berikut : melindungi konsumen sama artinya dengan melindungi seluruh bangsa sebagaimana diamanatkan oleh tujuan pembangunan nasional menurut UUD 1945; melindungi konsumen perlu untuk menghindarkan konsumen dari dampak negatif penggunaan teknologi; melindungi konsumen perlu untuk melahirkan manusia-manusia yang sehat rohani dan jasmani sebagai pelakupelaku pembangunan, yang berarti juga untuk menjaga kesinambungan pambangunan nasional; melindungi konsumen perlu untuk menjamin sumber dana pembangunan yang bersumber dari masyarakat konsumen. Agar konsumen

${ }^{22}$ Celina Tri Siwi Kristiyanti, Op. Cit., hlm. 10.

23 AZ. Nasution, Pengantar Hukum Perlindungan Konsumen, Penerbit Daya Widya, Jakarta, 1999, hlm. 13.

24 Shidarta, Op.Cit., hlm.16 6.

${ }^{25}$ Janus Sidabalok, Hukum Perlindungan Konsumen di Indonesia, PT. Citra Aditya Bakti, Bandung, 2006, hlm. 
memiliki pengetahuan dan informasi serta memiliki kesadaran akan hak-haknya maka perlu dilakukan pemberdayaan konsumen. Pemberdayaan merupakan terjemahan dari kata empowerment, berasal dari bahasa latin yaitu potere yang artinya memampukan. Ada 3 makna kata "empowerment", yaitu 1. the giving or delegation of power or authority; authorization; 2. the giving of an ability; enablement or permission. Pemberdayaan merujuk pada menjadikan pihak yang diberdayakan mampu bertindak oleh karena kekuatan dan energi yang dimilikinya dihasilkan dari suatu pemikiran, ikhtiar dan akal ("sehat"). Ditinjau dari hasil, pemberdayaan menghasilkan akal, pikiran dan ikhtiar sehingga mampu mengambil keputusan oleh karena dorongan yang kuat untuk bertindak. Pemberdayaan menunjukkan keterlibatan pihak yang diberdayakan; terbangun pikiran, akal dan ikhtiar; ada pengambilan keputusan serta ada tindakan nyata oleh dan untuk diri orang yang diberdayakan. ${ }^{26}$ Melalui upaya pemberdayaan berarti konsumen menjadi berdaya, mempunyai kemampuan untuk menunjukkan diri dan eksistensinya sebagai konsumen berarti juga konsumen memiliki kesadaran akan hak-hak dan kewajibannya sebagai konsumen dalam hubungan antaraprodusen-konsumen. ${ }^{27}$

Pemberdayaan konsumen adalah sebagai upaya yang ditujukan untuk memberikan perlindungan kepada konsumen melalui pengakuan dan pemenuhan akan hak-haknya yang memadai secara hukum. Cakupan dari pemberdayaan ini meliputi kebijakan luas, yakni:28 Pembuatan hukum dan peraturan perundangundangan yang bersifat adil, seimbang, dan mengakui hak konsumen; Sikap dan kebijakan pengambil keputusan yang responsif terhadap masalah konsumen; Pengaturan hukum yang menata berbagai kewajiban dan tanggung jawab yang harus dilaksanakan oleh pelaku usaha atas barang dan jasa mulai dari proses produksi hingga sampai ke tangan konsumen; Mengkondisikan para pelaku usaha untuk bersifat etis dan bertanggung jawab secara moral atas keselamatan, keamanan dan kenyamanan dari barang atau jasa yang diproduksi serta dipasarkan; Merangsang kepekaan masyarakat luas untuk peduli kepada

${ }^{26}$ Hotma Rumahorbo, "pemberdayaan masyarakat sarat makna", http://www.promkes.depkes.go.id/ index.php/topik-kesehatan/, diakses tanggal 1 Maret 2013.

${ }^{27}$ Janus Sidabalok, Hukum Perlindungan... Op. Cit., hlm. 259.

28 N.H.T. Siahaan, Hukum Konsumen: Perlindungan Konsumen dan Tanggung Jawab Produk, Penerbit Panta Rei, Jakarta, 2005, hlm. 91-92. 
perlindungan konsumen melalui tumbuhnya organisasi-organisasi swadaya yang membela nasib para konsumen; Menyediakan sarana-sarana yang bersifat mendidik sehingga tercipta kondisi masyarakat yang sadar konsumen; Memberdayakan pengadilan dan lembaga-lembaga pembelaan konsumen untuk selalu komitmen kepada keberpihakan hukum dan keadilan, yang selama ini belum dinikmati oleh konsumen secara lebih optimal.

Dari pengertian-pengertian di atas terlihat jelas bahwa pemberdayaan konsumen berkaitan erat dengan hak-hak serta implementasinya secara nyata. Tanpa adanya pengakuan hak-hak konsumen, maka tidak akan ada pula perlindungan konsumen, demikian pula tidak akan ada pemberdayaan, jika tida ada perlindungan dilakukan terhadap konsumen. ${ }^{29}$ Dalam merumuskan model pemberdayaan konsumen perlu diketahui pemahaman konsumen di Propinsi Lampung mengenai keamanan pangan yang dilakukan melalui penyebaran quisioner kepada 63 konsumen yang tersebar di 6 kabupaten/kota, hasil jawaban konsumen sebagai berikut: Responden yang pernah mendengar istilah keamanan pangan sebanyak 47 orang $(74 \%)$, yang tidak pernah mendengar istilah keamanan pangan sebanyak 16 orang (26\%), dengan rincian 6 orang di Kabupaten Lampung Selatan, 5 orang di Kabupaten Tanggamus, 1 orang di Bandar Lampung, 4 orang di Kabupaten Pringsewu. Dari 26\% responden yang menjawab tidak mendengar istilah keamanan pangan yang terdapat sebanyak 6 orang di Lampung Selatan itu berarti bahwa sebanyak 60\% responden tidak tahu istilah keamanan pangan. Angka tersebut sangat tinggi, hal memiliki korelasi dengan ditemukannya bahan kimia bernama Bleng atau Boraks yang diperjualbelikan dengan mudah di Pasar Tradisional Natar Kabupaten Lampung Selatan. Bahan kimia tersebut biasa digunakan masyarakat untuk membuat kerupuk gendar yang terbuat dari nasi yang dicampur dengan Bleng.

Terhadap pertanyaan yang kedua, yaitu apakah konsumen memahami bahwa makanan sangat berpengaruh terhadap kesehatan. Hasil jawaban responden menyatakan 63 orang (100\%) memahami bahwa makanan sangat berpengaruh terhadap kesehatan, jawaban ini mengandung makna bahwa 
konsumen sadar bahwa makanan yang dikonsumsi akan sangat berpengaruh terhadap kesehatan, hal itu berarti bahwa jika mengkonsumsi produk pangan yang tidak aman karena mengandung bahan berbahaya maka kesehatan akan terganggu. Terkait dengan produk pangan yang tidak aman dikonsumsi maka ditanyakan Apakah pernah mendengar pangan yang tercemar zat kimia, jawaban responden adalah 54 orang atau $85 \%$ menyatakan pernah mendengar dan sebanyak 9 orang atau $15 \%$ menyatakan tidak pernah mendengar produk pangan tercemar, pertanyaan ini berkaitan erat dengan pertanyaan apakah mengetahui/pernah mendengar tentang formalin, boraks, rhodamin B, metil Yellow? Terhadap pertanyaan ini sebanyak 55 responden menyatkan pernah mendengar, dan sebanyak 8 responden menyatakan tidak pernah mendengar.

Hasil jawaban responden tersebut dapat dinyatakan bahwa konsumen masih banyak yang belum mengetahui tentang bahaya produk pangan yang mengandung bahan kimia berbahaya. Sumber informasi atau pengetahuan responden tentang bahaya produk pangan tercemar diperoleh melalui Televisi, radio, koran, pabrik, warung, internet, sosial media. Media informasi yang dinyatakan 50 responden sebagai sumber informasi adalah Televisi. Jika diperhatikan hasil jawaban responden di atas maka tidak ada responden yang menyatakan sumber informasi yang lain misalnya melalui leaflet, brosur, spanduk atau sosialisasi langsung. Hal ini menandakan bahwa pemerintah belum optimal dalam melakukan penyebaran informasi kepada masyarakat, jawaban responden ini terkait erat dengan pertanyaan nomor 10 yaitu: 1. Apakah pemerintah (pemerintah Propinsi, Kabupaten, Kecamatan, Kelurahan/Desa/Kampung) atau pihak lain pernah menyampaikan informasi atau sosialisasi tentang bahaya pangan yang tercemar zat kimia di tempat bapak/ibu/saudara/i? terhadap pertanyaan ini sebanyak 37 orang menyatakan tidak pernah dilakukan sosialisasi sedangkan yang menjawab pernah dilakukan sosialisasi sebanyak 26 orang responden .

Selanjutnya yang perlu diperhatikan adalah jawaban 63 orang responden atau $100 \%$ menyatakan perlu informasi tentang cara mengenali atau mengidentifikasi produk pangan yang menggunakan boraks, formalin, rhodamin b, metil yellow. Hal ini menjadi alasan ilmiah untuk dilakukan permberdayaan konsumen dari ancaman bahaya produk pangan tercemar bahan kimia. Model yang dapat dilakukan untuk 
meningkatkan pengetahuan konsumen yaitu Model Pendidikan Konsumen. Metode pemberdayaan berupa penyebaran informasi atau pengetahuan mengenai cara mengenali atau mengidentifikasi produk pangan yang menggunakan bahan tambahan pangan yang dilarang penggunaannya sebagai bahan tambahan pangan. Perlunya upaya ini dilakukan karena sebagian besar masyarakat Lampung mengetahui tentang keamanan pangan melalui televisi, radio, koran sedangkan media sosialisasi lain belum dikenal masyarakat dengan demikian perlu digunakan sarana sosialisasi dalam bentuk penyebaran leaflet, spanduk. Media sosialiasasi ini lebih sederhana karena berupa tulisan, gambar sehingga masyarakat akan lebih mudah memahami pesan yang ingin disampaikan melalui media tersebut. Selain itu pendidikan konsumen dapat dilakukan dengan cara penyuluhan secara langsung kepada masyarakat dengan metode ceramah, diskusi, presentasi audio visual.

Informasi yang disampaikan berupa cara mengenali produk pangan yang terindikasi tercemar atau menggunakan bahan tambahan pangan yang dilarang penggunaan pada produk pangan seperti Formalin, Boraks, Rhodamin B, Metanil Yellow. Dalam rangka meningkatkan pengetahuan hukum maka disampaikan pengetahuan hak-hak konsumen yang diatur dan dijamin Undang-Undang Nomor 8 Tahun 1999 tentang Perlindungan Konsumen, yaitu: a. hak atas kenyamanan, keamanan, dan keselamatan dalam mengkonsumsi barang dan/atau jasa; b. hak untuk memilih barang dan/atau jasa serta mendapatkan barang dan/atau jasa tersebut sesuai dengan nilai tukar dan kondisi serta jaminan yang dijanjikan; c. hak atas informasi yang benar, jelas, dan jujur mengenai kondisi dan jaminan barang dan/atau jasa; $d$. hak untuk didengar pendapat dan keluhannya atas barang dan/atau jasa yang digunakan; e. hak untuk mendapatkan advokasi, perlindungan, dan upaya penyelesaian sengketa perlindungan konsumen secara patut; f. hak untuk mendapat pembinaan dan pendidikan konsumen; g. hak untuk diperlakukan atau dilayani secara benar dan jujur serta tidak diskriminatif; $h$. hak untuk mendapatkan kompensasi, ganti rugi dan/atau penggantian, apabila barang dan/atau jasa yang diterima tidak sesuai dengan perjanjian atau tidak sebagaimana mestinya; i. hak-hak yang diatur dalam ketentuan peraturan perundang-undangan lainnya. 
Perlunya penyampaian informasi tentang hak konsumen agar konsumen dapat mengetahui dan memahami bahwa perbuatan menggunakan bahan tambahan pangan yang dilarang adalah suatu perbuatan melanggar hukum sehingga konsumen dapat menggugat pelaku usaha yang melanggar hak-hak konsumen. Kesadaran, kepatuhan hukum dan perilaku konsumen juga menentukan di dalam praktik perlindungan dan penegakkan hukum.30 Penyelesaian sengketa konsumen dapat ditempuh melalui jalur litigasi yaitu penyelesaian sengketa melalui lembaga peradilan dan melalui nonlitigasi yaitu penyelesaian sengketa di luar pengadilan, sebagaimana diatur dalam Pasal 45 menyatakan: Setiap konsumen yang dirugikan dapat menggugat pelaku usaha melalui lembaga yang bertugas menyelesaikan sengketa antara konsumen dan pelaku usaha atau melalui peradilan yang berada di lingkungan peradilan umum; Penyelesaian sengketa konsumen dapat ditempuh melalui pengadilan atau di luar pengadilan berdasarkan pilihan suka rela para pihak yang bersengketa.

Ketentuan di atas menentukan ada dua pilihan yang dapat ditempuh konsumen dalam penyelesaian sengketa konsumen yaitu melalui lembaga yang bertugas menyelesaikan sengketa antara konsumen dan pelaku usaha atau melalui peradilan yang berada di lingkungan peradilan umum. Lembaga yang khusus di bidang penyelesaian sengketa konsumen adalah Badan Penyelesaian Sengket Konsumen (BPSK), yang dibentuk pemerintah. Lembaga ini bukanlah lembaga peradilan, pola penyelesaian sengketa pada lembaga ini berupa mediasi, negosiasi, konsiliasi dan arbitrase. Sedangkan penyelesaian sengketa melalui pengadilan memiliki prosedur formal. Tidak mudah bagi masyarakat awam untuk melakukan proses gugatan di pengadilan karena diperlukan kegiatan penyusunan gugatan, pendaftaran perkara, penjadwalan sidang, pelaksanaan sidang yang berisi tahaptahap pembacaan gugatan, jawaban atas gugatan, putusan sela, pembuktian, putusan hakim. Dalam kegiatan pemberdayaan konsumen tahapan proses persidangan

30 Irna Nurhayati, “Efektivitas Pengawasan Badan Pengawas Obat dan Makanan terhadap Peradaran Makanan terhadap Peredaran Produk Pangan Olahan Impor dalam Mewujudkan Perlindungan Konsumen" dalam Mimbar Hukum, Vol. 21 No. 2, Juni 2009, hlm. 218-219. Lihat juga KN. Sofyan Hasan, "Pengawasan dan Penegakan Hukum terhadap Sertifikasi dan Labelisasi Halal Produk Pangan" Jurnal Hukum IUS QUIA IUSTUM, Vo. 22 No. 2 April, 2015, hlm. 3012. 
tersebut disampaikan kepada konsumen, agar konsumen memiliki pengetahuan dan pemahaman tentang prosedur dan mekanisme proses persidangan.

\section{Penutup}

Berdasarkan hasil penelitian dan pengkajian disimpulkan: Pertama, upaya pengendalian yang dilakukan pemerintah dalam mengendalikan produk pangan tercemar, yaitu dilakukan dengan cara: a) mengeluarkan kebijakan tentang larangan menggunakan bahan tambahan pangan yang mengandung zat kimia, secara khusus diatur dalam Peraturan Menteri Kesehatan Republik Indonesia Nomor 33 Tahun 2012 tentang Bahan Tambahan Pangan yang melarang penggunaan formalin, boraks, rhodamin $b$, metil yellow sebagai bahan tambahan pangan; b) melakukan pengawasan terhadap produk pangan yang beredar di pasaran. Kedua, model pemberdayaan konsumen yang dapat dilakukan adalah pendidikan konsumen berupa penyampaian informasi atau pengetahuan tentang cara mengidentifikasi produk pangan yang mengandung bahan tambahan pangan yang dilarang penggunaannya pada produk pangan; menyampaikan informasi atau pengetahuan hak-hak konsumen dan cara penyelesaian sengketa konsumen yaitu melalui pengadilan dan di luar pengadilan.

Mengingat besarnya dampak produk pangan terhadap kesehatan manusia sehingga perlu ditingkat sosialisasi kepada berbagai lapisan masyarakat berupa pengenalan tentang bahaya produk pangan yang menggunakan bahan tambahan pangan yang dilarang, dengan tujuan agar konsumen dapat terhindar dari ancaman bahaya produk pangan tercemar bahan kimia berbahaya.

\section{Daftar Pustaka}

\section{Buku}

Sutedi, Adrian, Tanggung Jawab Produk Dalam Hukum Perlindungan Konsumen, Ghalia Indonesia, Bogor, 2008.

Nasution, AZ., Pengantar Hukum Perlindungan Konsumen, Penerbit Daya Widya, Jakarta, 1999.

Siwi Kristiyanti, Celina Tri, Hukum Perlindungan Konsumen, Sinar Grafika, Jakarta, 2009.

Saparinto, Cahyo, dan Diana Hidayati, Bahan Tambahan Pangan, Kanisius, Yogyakarta, 2006. 
Siahaan, N.H.T., Hukum Konsumen: Perlindungan Konsumen dan Tanggung Jawab Produk, Panta Rei, Jakarta, 2005.

Sidabalok, Janus, Hukum Perlindungan Konsumen Di Indonesia Dengan Pembahasan Atas Undang-Undang Nomor 8 Tahun 1999, PT Citra Aditya Bakti, Bandung, 2006.

Cahyadi, Wisnu, Analisis\&Aspek Kesehatan Bahan Tambahan Pangan, PT Bumi Aksara, Jakarta, 2006.

\section{Laporan Penelitian}

Data Statistik, Sentra Informasi Keracunan Nasional Badan Pengawas Obat dan Makanan RI, 2010.

Laporan Tahunan 2013 Badan Pengawas Obat dan Makanan.

Laporan Tahunan Balai Besar Pengawas Obat dan Makanan Bandar Lampung Tahun 2013

Laporan Penelitian Hukum, Tanggung Jawab Pemerintah Dalam Menjamin Perlindungan Pangan (Perbandingan Dengan Beberapa Negara)" Badan Pembinaan Hukum Nasional RI, 2013.

\section{Artikel Jurnal}

Mohamad Fazli, Sabri. "The Development of Consumer Protection Policies in Malaysia." International Journal of Business and Social Research 4 (6) 2014.

Nurhayati, Irna, "Efektivitas Pengawasan Badan Pengawas Obat dan Makanan terhadap Peradaran Makanan terhadap Peredaran Produk Pangan Olahan Impor dalam Mewujudkan Perlindungan Konsumen" dalam Mimbar Hukum, Vol. 21 No. 2, Juni 2009.

Sofyan Hasan, KN., "Pengawasan dan Penegakan Hukum terhadap Sertifikasi dan Labelisasi Halal Produk Pangan" Jurnal Hukum IUS QUIA IUSTUM, Vo. 22 No. 2 April, 2015.

\section{Peraturan Perundang-undangan}

Undang-Undang Nomor 8 Tahun 1999 tentang Perlindungan Konsumen (Lembaran Negara Republik Indonesia Tahun 1999 No, 42, Tambahan Lembaran Negara Republik Indonesia No. 3821).

Undang-Undang Nomor 36 Tahun 2009 tentang Kesehatan Konsumen (Lembaran Negara Republik Indonesia Tahun 2009 No. 144, Tambahan Lembaran Negara Republik Indonesia No. 5063).

Undang-Undang Nomor 18 Tahun 2012 tentang Pangan (Lembaran Negara Republik Indonesia Tahun 2012 No. 227, Tambahan Lembaran Negara Republik Indonesia No. 5360).

Peraturan Pemerintah Nomor 28 Tahun 2004 tentang Keamanan, Mutu dan Gizi Pangan. 
Peraturan Menteri Kesehatan Republik Indonesia Nomor 033 Tahun 2012 tentang Bahan Tambahan Pangan.

Peraturan Bersama Menteri Dalam Negeri Republik Indonesia Dan Kepala Badan Pengawas Obat Dan Makanan Republik Indonesia Nomor: 43 Tahun 2013/Nomor: 2 Tahun 2013 tentang Pengawasan Bahan Berbahaya Yang Disalahgunakan Dalam Pangan.

\section{Internet}

BBPOM di Bandar Lampung Musnahkan Produk Illegal Senilai 1 Milyar, http:/ / www.pom.go.id,di akses tanggal 3 Maret 2013.

Cahyono, Budi, Food Safety dan Implementasi Quality System Industri Pangan di Era Pasar Bebas, www.bappenas.go.id, diakses tanggal 11 Maret 2013.

Direktur Inspeksi dan Sertifikasi Pangan, Badan Pengawas Obat dan Makanan (BPOM) Suratmono saat acara media gathering bertema 'Pengawasan Keamanan Pangan', Senin, (16/7/2012); http://health.kompas.com/read/ 2012/07/17/0718222/ Teliti.7.Hal.Ini.Saat.Baca.Label.Makanan, diakses tanggal 1 Maret 2013.

Rumahorbo, Hotma, "pemberdayaan masyarakat sarat makna”, http://www.promkes. depkes.go.id/index.php/topik-kesehatan/, diakses tanggal 1 Maret 2013. 